\section{The medical aspects of the 1565 Great Siege of Malta}

\author{
Charles Savona-Ventura
}

\section{ABSTRACT}

The 1565 Siege of Malta served as a turning point in the westward Ottoman advance. The 4-month long siege was resisted by the indomitable belief of the defenders that their cause was just and holy. It also required prior detailed organisation to ensure sufficient war materials and that the overall health of the combatants and non-combatants was maintained throughout the months of the siege. This article reviews the contemporary and historical sources relating to the conflict to identify the medical operational plans used by the military during this historic siege.

\section{INTRODUCTION}

The 14-16th centuries saw a progressive extension of Ottoman rule over the Eastern Mediterranean and the Balkans starting with the fall of Constantinople in 1453 and Western Europe found itself directly threatened by the apparently irreversible Turkish encroachment. ${ }^{1}$ The Order of St. John, stationed in Europe's underbelly on the Island of Malta after their expulsion from Rhodes, had proved unable to protect the sister island of Gozo from Turgut Reis's raid in 1551, while Tripoli was lost to the Order in 1552. The Order of St. John was a hospital and military religious order set up originally in Jerusalem after the First Crusade. It was slowly pushed back westwards over the centuries by the Ottoman incursions until it was ceded the Maltese Islands in 1530. By the spring of 1563 , news had begun to filter into the West of the arming of a new Turkish armada at Constantinople. On 18 May 1565, the Siege of Malta by the Turkish forces commenced (Table 1). The siege was finally lifted on 12 September (Julian calendar). The defenders were led by the religious leader of the Order Fra Jean Parisot de la Valette; the besiegers by Piyale Pasha and Kizilahmedi Mustapha Pasa, eventually joined by Turgut Reis. ${ }^{2}$ In the 18th century, the French writer Voltaire wrote that 'nothing is so well known as the Siege of Malta'. This heroic

Correspondence to Prof Charles Savona-Ventura, Humanities, Medicine \& Science Foundation, University of Malta, Tal-Qroqq, Msida MSD 2090, Malta;charles. savona-ventura@um.edu.mt battle on a small island in the Central Mediterranean was viewed as the turning point in stopping the expansionist designs of the Ottoman Empire; a number of firsthand and secondhand accounts were written contemporaneously or in the immediate aftermath, ${ }^{3-6}$ while the subsequent historians of the Order of St. John ensured detailed coverage of the events. ${ }^{7-9}$

The expectation of a military conflict requires commanders to draw up a military operational plan which varies according to their respective objectives: the attacking forces desiring dominion over the defenders and the defenders wishing to hold out until the attackers withdraw or are defeated. The operational plan requires the incorporation of medical facets to maintain the health of the troops and non-combatants, to care for the injured and to make the best use of biological and psychological aspects of warfare.

\section{PUBLIC HEALTH MEASURES}

In siege warfare, an important consideration for the defending commander is the care of the combatants and noncombatants besieged within the fortifications; their numbers augmented by the populations seeking safety within the fortified towns and fortresses: Birgu (Fort St. Angelo), Senglea (Fort St. Michael), Fort St. Elmo and Citadel Mdina. The siege conditions and the population overcrowding posed particular public health issues that needed to be addressed to ensure sanitation and well-being.

Plans were needed to house the sudden augmentation in the population within the fortified towns resulting from the

Table 1 Timeline of the 1565 Siege of Malta

\begin{tabular}{ll}
\hline 18 May & Arrival of the Turkish Armada \\
25 May & Siege of fort St. Elmo starts \\
23 June & Fall of Fort St. Elmo \\
2 July & Arrival of a contingent of Christian re-enforcements (Piccolo Soccorso) \\
15 July & Assault of Senglea using sea and land troops \\
28 July & Assaults on Senglea and Birgu \\
7 August & Christian cavalry mounts attack of Turkish base camp at Marsa \\
7 September & Arrival of significant Christian re-enforcements (Gran Soccorso) \\
8 September & Siege lifted \\
12 September & Turkish Armada leaves \\
\hline
\end{tabular}

countryside refugees coupled with combatants arriving from overseas to assist the Order in the defence of the island. ${ }^{3} 10$ The housing problem was made worse by the necessary defence strategy of pulling down houses deemed as interfering with an adequate defence process, and the destruction of houses resulting from continuous bombardment by the enemy troops. ${ }^{3}$ While many of those without available housing were taken in by other families, the housing problem was partially solved by the erection of tents and temporary huts. ${ }^{11}$

Malta had long been dependent on a steady importation of grain from Sicily and the fortified towns held numerous vaults for the safe storage of large amounts of grain sufficient to last several months. The rumours of Turkish invasion had prompted an increased effort to augment stores. ${ }^{12}$ A good store of wheat was purchased and sent to Malta by the Prior of Messina, Signorino Gattinara. Also 'any ships they met with in the channel, which had cargoes of wheat, wine, or other foodstuffs, they brought back with them to Malta where they were well paid for their provisions'. ${ }^{3}$ On the 9 May 1565, when news of the departure of the Ottoman fleet was received, all wheat, oats and other agricultural products were collected and put into storage at Birgu. 213

Efforts were also made to reduce the number of unnecessary mouths to feed. Between April and May 1565, a 'great number of people' sailed to Sicily. ${ }^{8}$ A further batch of refugees had embarked on the Order's ships to leave for Sicily, but hostilities commenced before they could travel. ${ }^{9}$ In spite of this drive to wean out gente inhabile alla Guerra, the remaining population would have still topped 22000 with about a third being foreign or local combatants. Before the arrival of the Ottoman forces in Malta on 18 May, the country inhabitants were encouraged to go to the nearest forts with 
all their livestock, thus ensuring an augmentation of food supply within the fortifications but also depriving the attacking forces from supplies. The knights Luigi Balbiano and Adrian Maimon were entrusted to bring the inhabitants and their livestock into the fortified towns. To reduce disturbance and pressure on the food stores, all unnecessary animals were slaughtered. La Valette had his own dogs put down. ${ }^{3}$

Some inhabitants sought the protection of Fort St. Elmo taking shelter in the ditch around the fort. Because of the fort's small size and expecting heavy repeated assaults, 'the Grand Master ... gave orders that all the women, children, and old people who had taken shelter in the ditch around St. Elmo, should be sent over to Birgu. Only men who were fit to fight or work were to be kept there. The result was that, when the Turks attacked the fort, there were eight hundred fighting men defending it. He provisioned the garrison with biscuit, wine, cheese, salt pork, vegetables, oil, and vinegar. As for fresh meat they had the island cattle which had been kept in the ditch around the fort'. 310 The fort continued to be regularly supplied with provisions throughout the conflict until its fall.

In Birgu, the grain supply was generally sufficient and it was always allowed to sell grain by those who had it, and there was always enough to sell'. ${ }^{6}$ By 23 June, it became important to initiate a system of food distribution within Birgu when all inhabitants received three one-pound loaves daily. In addition, the Grand Master 'ordered all the corn and wine that was in private hands to be brought into the public magazines, paying the price thereof to the proprietors'. ${ }^{10}$ On 6 September, the bread ration of the soldiers and knights was reduced in some of the Auberges. ${ }^{3} 11$ The cereal grain was baked into bread and hard tack after being ground by the hand and animal operated mills in Birgu and the winddriven mills in Senglea. Some bartering for food also took place between the besiegers and the besieged. 'The Turks opposite St Michael gave Martello some local fruit, such as melons and oranges. In exchange for these he gave them some white bread and cheese. When the Turks saw this, they were dumb-founded, for they had been convinced that we were extremely short of food'. ${ }^{3}$

At Mdina, on 11 August, the remaining provisions included '200 oxen for food and an equal number of other bovines for our sustenance, and 1000 between sheep and goats, besides pigs which roam the country. ... There are 500 salme of wheat in the stores, and other 600 with private individuals, between grain and barley. We have 70 cantari of biscuit, but no wine, vinegar, or oil or any other provisions left ... advising you that the provisions which are to be brought over should be biscuit, as here no facilities for baking bread exist, except for our consumption'. 4 The problems of provisions were also a concern for the relieving forces since 'no way was found how to feed that army on an island so poor in victuals ... He ordered that on embarking and landing each person should carry so much biscuit as would last at least 30 days at the rate of 24 ounces per man per day ... Each one who landed received a sack with 75 libbre of biscuit'. ${ }^{6}$

The other essential commodity was adequate reserves of water. In January 1565 , an inspection of all the public and private wells and cisterns in Birgu and Senglea was made while arrangements were made to enable the storage facilities of 40000 barrels of water at Birgu to anticipate for the needs of the besieged there. ${ }^{11}$ Geronimo de Huete, Balthasar Empador and Antoine de Bourne were made 'responsible for seeing that water was continuously drawn from the Marsa to keep the cisterns of Birgu, St. Michael, and St. Angelo always full.' The water rationing was entrusted to the knights Antonio Pacheero Caraveo and Marco Antonio Altavilla. The Grand Master also 'apportioned the wells and water cistern, so that everyone knew where to draw his own ration'. ${ }^{3}$ In spite of these precautions, acute water shortage was felt by the first week of July 1565 . This was met with by rebellious actions by the Birgu populace sufficient to cause the Grand Master to consider expelling the civilians from the town. ${ }^{8}$ This was only circumvented by the discovery on 21 July of a water spring at Birgu while digging to extract stone for repairing the fortification walls. ${ }^{6}$

Public health under siege conditions also requires careful attention to environmental hygiene. Previous public health regulations had been placed in force addressing the abuse of public water supplies, the washing of hemp, the control of pigs in streets and the controlled slaughter of animals. ${ }^{14}$ The public health concerns became even more essential under siege conditions. A quick burial after a battle was essential, though notable knights or noblemen were laid out awaiting formal burial presumably after being embalmed. ${ }^{3}$ Burial during the Mediaeval period was generally carried out within the grounds of churches and chapels. ${ }^{15}{ }^{16}$ In 1574 , there were 17 chapels and churches in
Birgu, but Senglea boasted only one. ${ }^{17}$ These were insufficient to cater for the increased mortality brought on by the conflict. The knights and victims of the Great Siege were buried in the cemetery opposite the San Lorenzo-a-mare Church at Birgu. Their remains were later exhumed and reburied in the grounds of the St. John Conventual Church in Valletta. Some remains from the siege were reburied in 1787 in a common crypt sited in the grounds of Fort St. Angelo. Ensuring a regular Christian burial for all the dead who gave their life in this conflict was important to maintain religious and psychological morale. Many of the combatants were volunteers whose only presumed reward was a heavenly one. The combatants had received from Pope Pius IV a plenary indulgence and a pardon for all their sins. Thus 'if they fell in the siege, they would find a place in heaven'. ${ }^{3}$

The measures taken to dispose of the dead by the besieged were however not completely sufficient for public health control during and after the lifting of the siege. The great number of corpses and mangled human remains buried under the rubble attracted huge swarms of flies; an epidemic of high fever that occurred within the Birgu fortifications was attributed to the presence of these flies. ${ }^{3}$ Archaeological excavations have suggested that the Ottoman casualties were also buried, possibly at Marsa and Marsaxlokk. ${ }^{18}{ }^{19}$ Wild dogs roaming the countryside disinterred the superficially buried corpses to feast on their flesh. ${ }^{8}$

\section{FIRST-AID FACILITIES}

On the battlefield, the most important factor that determines whether an injured individual survives or not is the front-line first-aid management. This is where in the heat of the battle or the interim, tourniquets are applied to stop bleeding and burns are suitably managed. During the Great Siege, first-aid stations were set up on top of the battlements with barrels of salt water to manage and reduce the effects of burns. ${ }^{3}$ The defending combatants were particularly at risk of burns when handling some of the defence mechanisms. Burns could easily be caused by the flash of the firing musket and could also be experienced when handling the burning hoops and pitch/oil being thrown down on the attackers. Recorded examples of burn injuries on the defenders' side include Don Jaime de Sanoguera who had his face burnt by gunpowder but valiantly continued to fight, Commander Buoninsegna who was wounded by an incendiary and the 
Maltese tailor-soldier Marco who was burned to death by incendiaries. ${ }^{3}$

Fighting went on for hours on end often in the summer heat-in July and August the average temperature in Malta is $32^{\circ} \mathrm{C}$ with a maximum often above $36^{\circ} \mathrm{C}$. It was therefore necessary to ensure that nourishment in the form of food and fluids was at hand for the use of the combatants. 'The attacks lasted for nine hours, from daybreak until just after noon. The Turks were relieved more than a dozen times by fresh troops, while we refreshed ourselves with well-watered wine and a few mouthfuls of bread.... made available to all the posts which were engaged. ${ }^{3}$ Wine and vinegar were essential additives to help 'purify' the water which could easily become stale and contaminated leading to gastrointestinal disturbances. The effort needed to persist with fighting wearing bulky armour for hours on end led to 'many dying and falling exhausted by fatigue and by combat'. Even the fresh troops relieving the besieged in September succumbed to the temperature and as they advanced in the heat, many fainted and dropped dead..$^{5}$

Provisions were also needed to transport the severely wounded to the hospital. It is very likely that this would have been carried out by one's own comradesin-arms, though it may also have been a task assigned to the non-combatants. When the knight Abel de Bridiers de la Gardampe was shot during a battle at Fort St. Elmo, his comrades-at-arms went to his assistance to carry him to the Fort's chapel. He however refused their help and crawled to the chapel on his own initiative where he was later found dead. ${ }^{10}$ More organised transport was needed to transport the injured from the peripheral fronts at Fort St. Elmo and Senglea which did not have formal hospital services on site and the injured were regularly transferred to Birgu for treatment. A great stock of remedies for the sick and wounded was however kept in each of the fortifications. ${ }^{10}$

At Fort St. Elmo, the guardroom served as a first-aid station. The transport of the wounded from Fort St. Elmo to the Sacra Infermeria at Birgu was undertaken by boats clandestinely at night, until a total blockade of the fort was enforced by the besiegers. $^{3} 10$ Only the very severely wounded were transported to Birgu; the rest were treated on site and continued to fight on. The knight, Juan de la Creda, was branded a coward and jailed after he got himself evacuated from Fort St. Elmo for a minor injury. ${ }^{10} \mathrm{He}$ was subsequently released and sent back to the fort. When wounded again by a musket shot, rather than risk being re-branded a coward, he opted to receive medical attention on site and returned to the battle. La Creda was eventually killed during the fighting in Birgu on 19 August. ${ }^{10}$ Once the blockade was effectively enforced by the besiegers, the guardroom was used to house the non-walking injured. Thirty knights sought refuge there and surrendered to the janissaries when the fort fell on 23 June. Very little quarter was given and only seven knights were captured and kept alive to be eventually transferred to Ragusa pending their exchange with 30 Turkish prisoners. ${ }^{6} 20$

In the same courageous spirit, on 6 June, Captain Miranda stationed at Fort St. Elmo, after being badly wounded, refused to be evacuated and sat in a chair near the guns where he stayed to the end of the action. Similarly, Bailiff Negroponte was injured with an arrow in the leg but continued fighting. ${ }^{3}$ In the last stand of Fort St. Elmo, those knights who 'were not able to walk by reason of their wounds, had themselves carried in chairs to the side of the breach, where, armed with swords which they held in both hands, they waited with heroic resolution'. ${ }^{10}$

Senglea probably had a similar first-aid management station. Facilities for the transport of the injured depended on the wooden pontoon constructed between Senglea and Birgu, clearly visible in the d'Aleccio frescos (Figure 1). ${ }^{7}$ On July 13 , before the expected assault on Fort St. Michael, 'La Valette had a floating bridge, which had been constructed of barrels and planks, towed into position between Birgu and St. Michael, so that the latter could be quickly reinforced if the occasion arose. 3

\section{HOSPITAL SERVICES}

The expected casualties necessitated an augmentation in hospital services. After making the maritime town of Birgu their administrative centre, the Order quickly set out to build a Sacra Infermeria in that town, managed during the siege by Fra Gabriel Ceralta. ${ }^{321}$ However, this facility was inadequate to cope with the continuous inflow of injured on a daily basis for a 4-month period. The first big clash of the Great Siege took place on the 21 May when 150 people were wounded. Two days later the siege of Fort St. Elmo began. The injured were regularly transferred to Birgu, sometimes amounting up to 60 casualties per day. Throughout the conflict, the overall casualties averaged $100-400$ per day, ${ }^{11}$ though on 15 July, as many as 600 men were wounded in one day of conflict at Senglea. With this rate of casualties, the hospital quickly filled up to 200 inmates by 11 June. $^{3}$

On 6 June, emergency medical facilities were organised in the various Auberges of the Order and in suitable private houses which were evacuated and converted into casualty hospitals. ${ }^{3}$ Each emergency facility was assigned surgeons and chaplains, and provided with necessary medications. There was also a smaller supplementary hospital consisting of a large hall sited next to the Auberge d'Italie close to Fort St. Angelo. This had been set up about a decade earlier (around 1554) and was maintained by the Italian Knights. $^{22}$ When the Admiral Pedro de Monte fell ill owing to his ceaseless exertions and his advanced age, he retired to this facility to recuperate.

Care was taken 'to get in a great stock of wine, of provisions, and remedies for the sick and wounded ${ }^{10}$ and a large supply of medicaments had been stored before the onset of the hostilities. By August, the medicinal supply was running low. New supplies were shipped from Sicily, but the supply ship was captured by the besiegers. ${ }^{8} 21$ Medications were distributed freely as necessary. In a post-siege petition dated February 1566 made by Antonio de Lauda, the apothecary sought compensation from the Order for medication distributed freely to the population during the siege months. ${ }^{2}$

The Sacra Infermeria was also badly sited during the conflict since it was near the Post of Castille. The access to the infirmary was protected by the demolition of houses leading to it, while the gates leading to the foreshore were blocked and parapets were constructed. These were manned by soldiers under the command of lay officers of the Infirmary. A line of chain entanglements and underwater obstacles was created from Fort St. Angelo to the Post of Castille. The Post was repeatedly attacked, and on two occasions, 7 and 20 August, the Turkish forces penetrated a breach in the bastions in the area. On both occasions the defenders managed to repulse the Turks, on the latter occasion with the help of the 'walking injured'. ${ }^{10}$ The sick and injured continuously contributed to the war effort by replenishing the fighting supplies such as making fuses for the arquebuses. ${ }^{3}$

The fortified citadel Mdina was generally serviced by the eight-bedded Santo Spirito Hospital housed outside the walls and hence useless during the siege. ${ }^{23}$ With the onset of hostilities, the facilities at the hospital together with the facilities in the adjoining Franciscan monastery were 


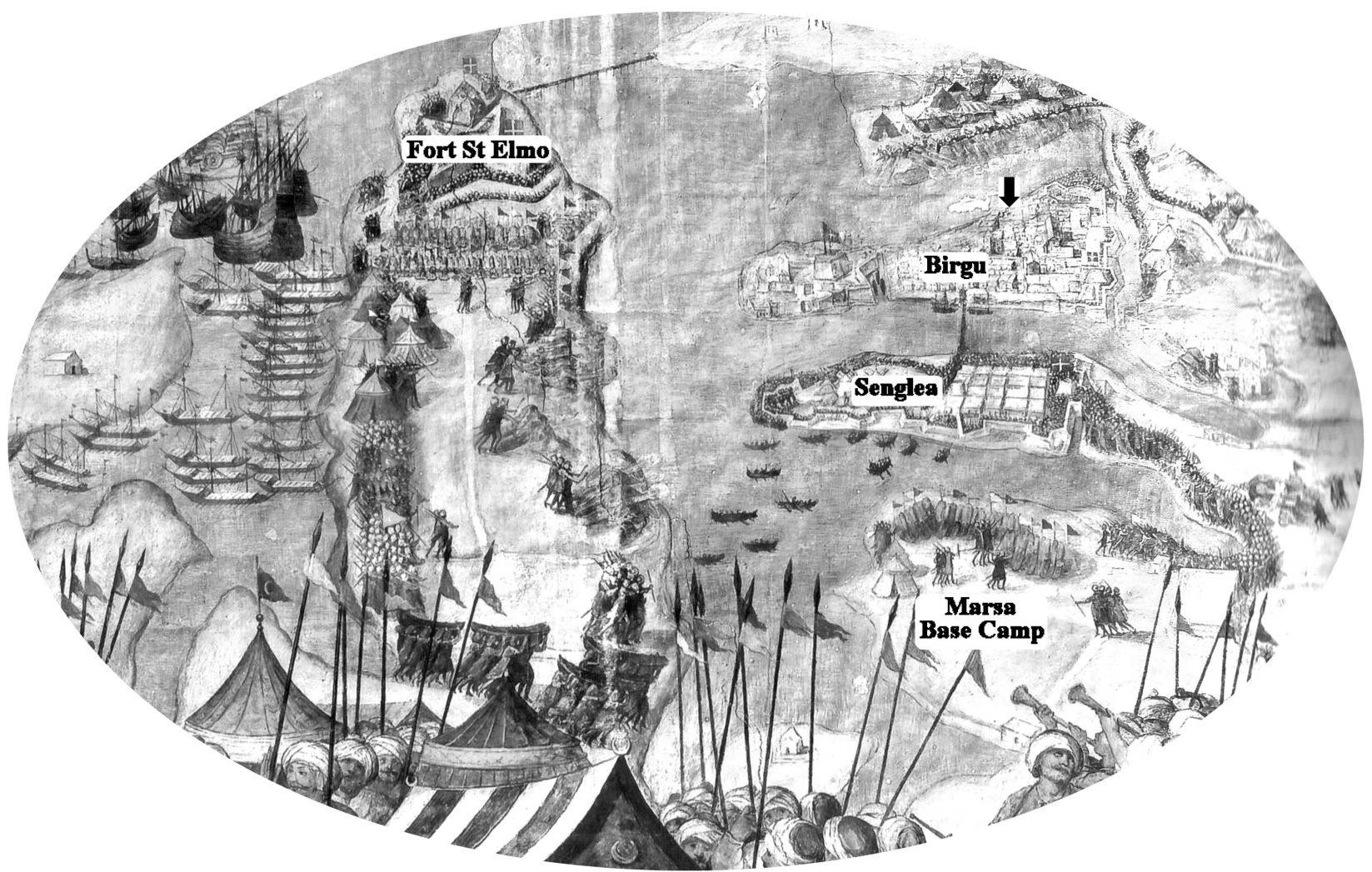

Figure 1 Detail from one of Matteo Perez d'Aleccio's frescoes at the Grand Master's Palace in Malta showing the various fortifications (arrow indicates locality of the Sacra Infermeria).

transferred to an edifice within the citadel walls for use of the sick and injured. This is evidenced by the post-siege request dated 1566 by the Franciscan Friars who requested the return of the beds that had been lent to the Mdina Universitá for the use of the wounded during the siege. ${ }^{24}$ While hostilities around Mdina were limited to skirmishes by the cavalry stationed there, these services were definitely used to treat the wounded such as the 29 gravely wounded horseman injured during a skirmish on 7 August. ${ }^{11}$

\section{THE OTTOMAN MEDICAL SERVICES}

The Ottomans also set up a number of medical stations in their various camps around the Grand Harbour region. Their main camp seems to have been that set up at Marsa where they knew that copious freshwater was available-being unaware that the source had been poisoned by the knights. The Marsa camp was attacked by the Mdina Cavalry on 28 July who systematically slaughtered the sick, wounded and other non-combatants they found there. ${ }^{3}$ Since Marsa was close to a marshland region, the wounded soon fell ill with 'the blood flux (dysentery)' and 'other contagious distempers' such as 'putrid fevers' and 'tifo'. 810 The Turks 'had occupied some villages for the comfort of the lodgings and of the few cisterns that are on the island, by nature very parched'. ${ }^{6}$ The besiegers experienced difficulties in assisting the wounded on the front line since any attempt to help the wounded exposed the assistants making them easy targets for the defenders. Many of the wounded were therefore abandoned to die in the trenches dying 'like dogs in tens a day'. 811

When the Ottoman fleet had set sail for Malta, it carried provisions sufficient for 6 months, but this had been greatly reduced by the loss of a large merchantship in the Nauplia Channel. Further provisions consisting of raisins, dates, honey, oil and other things were furnished by the Bey of Tunis. By 12 June, however, the 'provisions (of the Ottoman forces) were very scarce in the army ... the labourers were rationed to ten ounces of biscuit a day, and ... many were dying from disease ... A vessel was dispatched by the pashas to Tripoli, together with a barge and four galleys. These ... were full of sick and wounded. It was planned that they should return with provisions for the army, since they were short of honey, oil, raisin, butter, and other delicacies which the Muslims relish'. ${ }^{3}$ By the end of August, the Turkish base hospital camp could not accommodate more casualties/sick and the galleys at anchor in Marsamxett were adapted as hospitals. ${ }^{25}$

\section{USE OF BIOLOGICAL WARFARE}

Another important aspect of the strategies used during the Great Siege was biological warfare. Prior to the siege, la Valette ordered that all wells and cisterns in the countryside were to be contaminated. The copious water spring at Marsa was also poisoned under the supervision of the Protomedicus Camillo Rossa using hemp, wheat, arsenic and other ingredients. Unsuspecting, the Ottomans continued to obtain their water supply from the Marsa spring right through the siege. ${ }^{3}$ The poisoning of the water sources had its effects on the Ottoman troops for 'besides sustaining many wounded, they had started suffering from a fever in their belly, caused by the discomforts, the lack of essentials and the almost insufferable heat of the season. Whereby many were dying all the time fading out of life and without any solace'. ${ }^{6}$ The Turkish ships obtained their water from a pool sited near the strait between Malta and Gozo, probably at St. Paul's Bay. At Fort St. Elmo, 'there was a freshwater pool nearby but, since they would not be able to use it, the defenders threw salt into it'. There was apparently a source of freshwater within the fort since 
the knights stationed in Fort St. Elmo proposed to 'ensure that the water in the fort was poisoned' if they were given permission to sally out of the fort and fight in the open. ${ }^{3}$

\section{PSYCHOLOGICAL WARFARE}

Both sides also used psychological warfare to boost their troop's morale and scare off the enemy. La Valette continually relied on the sense of honour and shame to maintain order and encourage his knights to die for the Order. Mercenary soldiers were encouraged to volunteer for dangerous duties at Fort St. Elmo with promises of higher pay and rewards. ${ }^{3}$ Religious sentiments were also encouraged among the troops and even more importantly among the non-combatant population. During the siege of Fort St. Elmo, a devout Capuchin friar of the Order of St Francis went to the fort and 'preached a sermon, encouraging the garrison and putting new heart into them for the fight. After hearing his words the men felt strengthened and consoled, and ready for whatever might befall.' Important Christian feast days such as Corpus Christi on 21 June were also celebrated with great pomp. ${ }^{3}$

Religious sentiment was also encouraged among the Ottoman troops. During the night prior to an assault, 'the Turks had been assembled on the high ground near the fort, shouting at the top of their voices, as is their custom when praying. Two hours before dawn their priests absolved them of their sins, exhorting them to fight well and to die for their false faith'. ${ }^{3}$ The Ottomans 'attacked with such wild courage that they were like afion-eaters-afion is a kind of drug which has such violent effects that, after eating a little of it, men lose their reason and become quite without fear.' The use of hashish by the Turks during the conflict was confirmed when this was found in the purses of dead soldiers. ${ }^{3}$

The continual psychological stress and pressure experienced by the Grand Master seem to have taken their toll and 'Grand Master La Valette, indomitable though his spirit was, was sorely tired (not without good reason), yet he concealed his feelings with his usual wisdom'. The efforts of a 'jester who had come to the island with Marshal Robles... kept La Valette informed of what was happening at the various posts; as well as trying to amuse him with his quips-although there was little enough to laugh about'. ${ }^{3}$ The morale of the combatants had to be maintained while measures were necessary to amuse the soldiers. La Valette was advised that 'from a morale point of view, be should dispatch some money to pay the troops-for nothing makes soldiers happier than money ... He had gaming tables set up, as well as bars, and the troops were naturally delighted'. 3

On their part, the Ottomans attempted to instil a sense of fear and foreboding in the defenders. During the assault of St. Elmo, 'so great was the noise, the shouting, the beating of drums, and the clamour of innumerable Turkish musical instrument, that it seemed like the end of the world'. ${ }^{3}$ They also tried to demoralise the defenders after the fall of Fort St. Elmo by beheading the fort's defenders and mounting these on stakes on the walls. In addition, the beheaded bodies were floated off on wooden boards towards Birgu. In retaliation, La Valette ordered the beheading of captured Turkish soldiers and the firing off of the heads towards the besiegers. ${ }^{3} 10$ This event is clearly depicted on one of Matteo Perez d'Aleccio's frescoes. ${ }^{7} \mathrm{He}$ also gave instructions that all Turkish prisoners were to be killed. The motive for this was to 'put his soldiers and the inhabitants, whatever extremes they might be reduced to, out of all hopes of capitulating, and to make them sensible, that their own preservation and that of the place were inseparable'. ${ }^{10}$

Both sides had to ensure discipline among the troops and anyone suspected of or caught deserting was punished severely. On the Turkish side, 'any man who was absent from his post would receive one hundred strokes on the belly'. On the defenders' side, traitors who were caught were quartered or hanged. '... A Greek, ... was tempted by the devil to go and tell the enemy that the relief force had arrived, as well as how to prevent them getting down to Birgu. ... He paid for his treachery by being quartered'. Dissent was also severely punished. An Italian from Genoa was hanged within sight of the enemy 'for saying publicly that we had no chance at all, and that it would be better for us to accept the money and the free passage that the Turks were offering. ${ }^{3}$

\section{THE AFTERMATH}

The 1565 Great Siege of Malta was a battle where no mercy was offered or requested. On the Christian side, 'over two thousand five hundred soldiers of all nationalities died in the siege. Seven thousand Maltese men, women, girls and boys were also killed, as well as five hundred slaves belonging to the Order'. The siege had a minimal effect on population growth and in 1567, the number of baptisms in most villages did not differ significantly from those years before the siege suggesting that the structure of the local population was not significantly altered by the fighting. ${ }^{26} 27$ The death toll of the Ottoman force was heavier estimated at $35000 \mathrm{men}^{3}$ or $40 \%$ of the fighting force. ${ }^{2}$

The medical consequences of the siege continued-in those who had suffered direct war injuries, and from deaths resulting from the adverse post-siege conditions. After the lifting of the siege, conditions did not immediately improve and the adverse health conditions persisted. About half of the Florentine troops left in Malta after the siege 'never saw their homes again for they died from the hard conditions and from disease' ${ }^{3}$ On a personal level, individuals were left maimed for life claiming financial assistance for their sacrifice during the battle. Individuals who received such aid from the Order years after the event included: Didaco di Aranda and Ludovico Rocca who each lost an arm while Nicolo de Alvarano, Sigismund Talhamar and Benedict Sanguineo sustained a leg injury that left them crippled. Pedro di Escovedo was severely wounded by a bullet in the throat and lost his speech. ${ }^{2}$ Fra Geronimo Zaportella suffered from mente captus requiring curators to be appointed to care for his needs. ${ }^{28} 29$

\section{Funding None.}

\section{Competing interests None.}

Provenance and peer review Not commissioned; externally peer reviewed.

To cite Savona-Ventura C. J R Army Med Corps 2014:160:1-6

Received 29 June 2013

Revised 15 July 2013

Accepted 16 July 2013

Published Online First 18 September 2013

J R Army Med Corps 2014;160:1-6.

doi:10.1136/jramc-2013-000137

\section{REFERENCES}

1 Gibbon E. The history of the decline and fall of the Roman Empire. London: Murray, 1862; Chapter 68

2 Spiteri SC. The Great Siege. Knights vs Turks MDLXV. Anatomy of a Hospitaller victory. Malta: Gutenberg, 2005

3 Balbi di Correggio F. La verdadera relacion de todo lo que el Anno de M.D.LXV ha succedido en la Isla de Malte. Barcelona 1568; English translation: Bradford E. The siege of Malta 1565. England: Penguin Books, 2003.

4 Letter dated 11th August 1565 from Fra Vincenzo Anastagi to Ascanio della Corgna. In Pellini P. Dell historia di Perugia, Venice: Gio Giacomo Hertz, vol 1: 1066-1073; English translation in Bonello G. Histories of Malta — versions and diversions. vol. 3. Malta: Fondazzjoni Patrimonju Malti, 2002:123-34. 
5 Bonello G. ed. Pallavicino Rangone-inordinate critic of de Valette. Histories of Malta - confessions and transgressions. vol. 9. Malta: Fondazzjoni Patrimonju Malti, 2008:58-66 (based on document housed in the Vatican Archives, Miscellanea, Armadio II, 14, f.38).

6 Adriani GB. Istoria de suoi tempi, Florence, 1583, 727-45. English translation in Bonello G. Histories of Malta-confessions and transgressions. vol. 9. Malta: Fondazzjoni Patrimonju Malti, 2008:39-56.

7 Lochhead IC. The Siege of Malta 1565-Matteo Perez d'Aleccio's frescoes in the Grand Masters' Palace, Valletta. Malta: Heritage Malta, 2009.

8 Bosio G. Dell'Istoria della Sacra Religione et III.ma Militia di San Giovanni Gerosolimitano. Rome: Facciotto, 1602; Parte III: 280, 307, 325, 502, 503, 511

9 Baudoin J. Histoire des Chevaliers de l'Ordre de S. lean de Hierusalem. Paris: Jacques d'Allin, 1643:484-6.

10 Vertot R. The history of the Knights of Malta. London: G. Strahan, 1728; volume 2.

11 Zabarella CS. Lo assedio di Malta-Maggio Settembre 1565. Torino: Tip. Salesiana, 1902.

12 National Malta Library. Universitá Ms 13, fol.338. In: Cassar C, Cutajar D. Malta and the 16th century struggle for the Mediterranean. Mid-Med Bank Report, 1985:22-59.

13 National Malta Library. Archives of the Order of Malta 90, fol.152.

14 National Malta Library. Universitá Ms 13 (23. vii.1538), fol.162-163v.

15 Ramaswamy S, Pace JL. The Medieval skeleton remains from St. Gregory's Church at Zejtun (Malta): Part I. Paleopathological studies. Arch Ital Anat Embriol 1979:84:43-53

16 Blagg TFG, Bonanno A, Lutrell AT. eds. Excavations at Hal Millieri, Malta: a report of the 1977 campaign conducted on behalf of the National Museum of Malta and the University of Malta. Malta: University Press, 1990:84-95.

17 Aquilina G, Fiorini S. eds. Documentary sources of Maltese History. Part IV Documents at the Vatican. No.1 Archivio Segreto Vaticano Congregazione Vesdcovi e Regolari Malta: Visita Apostolica no.51 Mgr. Petrus Dusina, 1575. Malta: University Press, 2011.

18 Borg B. Workmen discover a Muslim cemetery. Times of Malta 11 February 2012.

19 Buhagiar CM. National Museum of Archaeology News: 1998 \& 1999. Malta Archaeol Rev 2000;4:45.
20 Letter in Ragusa Archives, n.d. (post-September 1565). In: Bonello G. Histories of Malta-mysteries and myths. vol. 8. Malta: Fondazzjoni Patrimonju Malti, 2007:27-53

21 Cassar P. Medical history of Malta. London: Wellcome Historical Medical Library, 1965:37-44.

22 Darmanin Demajo G. Storia dell'albergia della lingua d'Italia. Archivio Storico di Malta 1929:1:261.

23 Fiorini S. Santo Spirito Hospital at Rabat, Malta-the early years to 1575. Malta: Department of Information, 1989.

24 Mifsud A. Un cenno al 1565 nel 1915. Archivum Melitense 1917 July, 231

25 Curione CS, Mizzi EF. Nuova storia della Guerra di Malta 1565. Roma: Tipografia Leonina, 1927.

26 Archivum Paroeciae. As reported in: Ciappara F. Marriage in Malta in the late eighteenth century. Malta: Associated News Ltd, 1988:126.

27 Savona-Ventura C. War and population change in the Maltese context. Malta Med J 2006;18:35-40

28 National Malta Library. Archives of the Order of Malta 91, f.185v.

29 Bonello G. ed. In and out of the Knights' prisons. In Histories of Malta - convictions and conjectures. vol. 4. Malta: Fondazzjoni Patrimonju Malti, 2003:9-43. 